\title{
SENSOR ARUS SEBAGAI PENGAMAN
}

\author{
I wan Fitrianto ${ }^{1}$ \\ Edy Victor Haryanto ${ }^{2}$
}

e-mail: iwan@potensi-utama.ac.id, edy@potensi-utama.ac.id

Diterima: 4 Desember 2009/Disetujui: 18 Desember 2009

\begin{abstract}
ABTRACT
This research the current design as a safety sensor motor driver. This application is perfect for contest that requires robots Indonesia currents and great power to move the mechanical robots. Purpose of using the flow sensor is to protect the driver motor so as not to burn tongs and set the pins in the power of holding the object as we need. Current sensor consists of a shunt resistor and the optocoupler. Shunt resistor connected in series with the motor, while the input of the OPTO-coupler is connected parallel with a shunt resistor. Increasing the current in the circuit would lead to increased tension in the shunt resistor. At a certain voltage so that the optocoupler will be activated from the OPTO will provide a logic 0 to be processed by the microcontroller and gave orders to stop the motor. Resistance value to adjust the clamp force obtained from theoretical calculation and the data loads in current sensor circuit.
\end{abstract}

Keywords: current sensors, optocoupler, microcontroller

\section{ABSTRAKSI}

Penelitian ini membahas tentang rancang bangun sensor arus sebagai pengaman driver motor. Aplikasi ini sangat tepat untuk kontes robot indonesia yang membutuhkan arus dan daya yang besar untuk menggerakkan mekanik robot. Tujuan penggunaan sensor arus adalah untuk melindungi driver motor penjepit supaya tidak terbakar dan mengatur kekuatan jepit dalam memegang objek sesuai yang kita butuhkan. Sensor arus terdiri dari resistor shunt dan optocoupler. Resistor shunt dihubungkan secara serial dengan motor, sedangkan input dari opto-coupler dihubungkan parallel dengan resistor shunt. Peningkatan arus pada rangkaian akan menyebabkan peningkatan tegangan pada resistor

1. Dosen Jurusan Teknik Informatika, STMIK Potensi Utama Jl. K.L. Yos Sudarso Km. 6,5 No. 3 A Tj. Mulia, Medan, Telp (061) 6640525

2. Dosen Jurusan Teknik Informatika, STMIK Potensi Utama

Jl. K.L. Yos Sudarso Km. 6,5 No. 3A Tj. Mulia, Medan, Telp (061) 6640525 
shunt. Pada tegangan tertentu optocoupler akan aktif sehingga dari opto tersebut akan memberikan logika 0 yang akan diolah oleh mikrokontroller dan memberikan perintah untuk menghentikan putaran motor. Nilai resistansi untuk mengatur kekuatan penjepit diperoleh dari hitungan secara teoritis dan beberapa pengambilan data pada rangkaian sensor arus.

Kata kunci : sensor arus, optocoupler, mikrokontroler

\section{A. Latar Belakang}

Perkembangan dunia komputer, terutama mikrokomputer/ mikroprosesor, memberikan dampak yang sangat besar terhadap dunia robotika, yang berkembang dengan begitu pesat. Hal ini tentu saja menuntut manusia untuk dapat mengikuti perkembangannya. Setiap tahun selalu diadakan kontes robot, baik tingkat Indonesia maupun tingkat Asia Pasifik, yang dapat berguna untuk mengasah ketrampilan mahasiswa dalam menciptakan suatu robot untuk menyelesaikan permasalahan yang ada. Dimana cara kerja robot tersebut menjepit suatu objek dengan menggunakan bantuan sensor arus yang berfungsi sebagai pengaman driver motor penjepit,. Diperlukan suatu kontrol yang baik supaya robot dapat bergerak menuju tiang yang diinginkan, serta pemilihan jalur yang tepat. Untuk itulah diperlukan perancangan sebuah robot otomatis yang dapat bergerak secara mandiri pada lapangan Robot ini dapat bergerak mandiri karena robot memiliki beberapa kemampuan(behaviour) untuk merespon beberapa informasi dari luar yang dibaca oleh sensor.

Kemampuan(behaviour) yang biasanya dimiliki oleh autonomous mobile robot antara lain :

. Reach Behaviour (kemampuan mencapai koordinat target).

Path Follower Behaviour (kemampuan untuk mengikuti jalur yang telah ditentukan).

Dengan menggunakan mikrokontroler, dapat dilakukan pengontrolan motor yang mengatur gerakan robot berdasarkan sensor yang ada untuk mencapai tujuan yang diinginkan. Selain harus memenuhi kemampuan robot seperti yang terdapat pada kriteria di atas, robot ini hendaknya dapat dikembangkan lebih lanjut agar bermanfaat bagi kehidupan manusia.

Kemungkinan kearah pengembangan dari robot ini adalah dapat diaplikasikan dalam dunia industri sebagai alat pengangkut barang otomatis karena di dalam robot ini diberikan kemampuan untuk memindahkan obyek dari suatu titik ke titik lain yang telah ditentukan. 


\section{B. Rumusan Masalah}

a. Bagaimana membuat rangkaian sensor arus untuk driver motor.

b. Apakah alat yang dibuat dapat meminimalisir kerusakan pada driver motor terutama untuk driver motor yang membutuhkan arus yang besar.

\section{Tujuan Penelitian}

Tujuan yang ingin dicapai dalam penelitian ini adalah:

a. Mengetahui arus yang dibutuhkan motor DC pada saat stall.

b. Memperkecil jumlah kerusakan yang di alami oleh driver motor.

c. Sebagai pengaman pada rangkaian driver motor.

\section{Batasan Masalah}

Asumsi-asumsi berikut ini sebagai batasan masalah yang dipakai dalam penelitian ini, yaitu :

1. Menciptakan bentuk atau model dari mekanik robot. Mikrokontroller AVR Atmega16 sebagai kontroller atau sebagai pengolah data input sehingga menjadikan data output untuk sistem pergerakan robot.

2. Membuat karakteristik sensor arus pada driver pada berbagai kondisi.

3. Membuat karakteristik sensor arus pada driver pada berbagai kondisi.

4. Mengamati dan mengananlisa apa saja kelemahan dan kelebihan dari sistem yang telah dibuat.

\section{E. Tinjauan Pustaka}

\section{Mikrokontroler ATmega16 (Datasheet Atmega16, www. alldatasheet.com)}

Bila sebuah mikroprosesor dikombinasi dengan I/O dan memori (RAM/ROM), maka akan dihasilkan sebuah mikrokomputer. Sebagai terobosan baru mikrokomputer ini juga dapat dibuat dalam bentuk single chip yaitu Single Chip Microcomputer (SCM) yang selanjutnya disebut mikrokontroler. 
Sebuah mikrokontroler mempunyai beberapa perlengkapan dasar untuk membangun sebuah komunikasi dengan plant diantaranya yaitu sebuah central processor unit (CPU), alamat, data, pengendali, memori, RAM, ROM, Input / Output.

A. CPU

Unit pengolah pusat (CPU) terdiri dari dua bagian yaitu unit pengendali (CU) dan unit aritmatika dan logika (ALU). Fungsi Utama pengendali adalah untuk mengambil, megkode, dan melaksanakan urutan instruksi sebuah program yang tersimpan dalam memori. Sedangkan unit aritmatika menangani proses perhitungan maupunbolean dalam hitungan.

\section{a) Alamat}

Pada mikrokontroler, apabila suatu alat dihubungkan dengan mikrokontroler maka harus ditetapkan terlebih dahulu alamat (address) dari alat tersebut. Untuk menghindari dua alat yang bekrja secara bersamaan yang mungkinakan menybabkan kerusakan .

\section{b) Data}

Mikrokontroler ATmega16 mempunyai lebar bus data 8 bit. Merupakan mikrokontroler CMOS 8 bit daya rendah berbasis arsitektur RICS yang ditingkatkan.

\section{c) Pengendali}

Selain bus alamat dan data bus mikroprosesor atau mikrokontroler dilengkapi juga dengan bus pengendali yang fungsinya untuk menyerempakkan operasi pada mikrokontroler dengan operasi luar.

\section{d) Memori}

Mikrokontroler memerlukan memori untuk menyimpan data / program. Ada beberapa tingkatan memori, diantarannya register internal, memori utama, dan memori massal. Sesuai dengan urutan tersebut waktu aksesnya dari yang lebih cepat ke yang lebih lambat.

\section{e) RAM}

RAM (Random Access Memory) merupakan memori yangdapat dibaca atau ditulisi. Data dalam RAM aka terhapus bila catu daya dihilangkan. Oleh karena itu program mikrokontroler tidak disimpan di dalam RAM. Ada dua teknolohi dalam membuat RAM yaitu RAM static dan RAM dynamic. 


\section{f) ROM}

ROM (Read Only Memory) merupakan memori yang hanya dapat dibaca. Data dalam ROM tidak akan terhapus meskipun catu daya dimatikan. Oleh karena itu ROM dapat digunakn untuk menyimpan program. Ada beberapa jenis ROM antara lain ROM, PROM, EPROM, EAPROM.

\section{g) Input/ Output}

I/O dibutuhkan untuk melakukan hubunhgan dengan piranti di luar sistem. I/O dapat menerima data dari alat lain. Ada dua perantara I/Oyang dipakai, yaitu piranti untuk hubungan serial (UART) dan piranti untuk hubungan paralel (PIO).

Mikrokontroler AVR ATmega16 merupakan seri mikrokontroler CMOS 8 bit buatan Atmel, berbasis arsitektur RICS (Reduced Instruction Set Computer) yang ditingkatkan. Hampir semua instruksi dieksekusi dalam satu siklus clock. AVR mempunyai 32 register general purpose, timer/counter fleksibel dengan metode compare, interrupt internal dan eksternal, serial UART, programmable watchdog timer dan mode power saving. Mempunyai ADC dan PWM internal. AVR juga mempunyai In-System Programmable Flash on-chip yang mengijikan memori program untuk diprogram ulang dalam sistem menggunakan hubungan serial SPI.

Beberapa keistimewaan ATmega16 adalah sebagai berikut :

1. Advanced RICS Architecture

a. 130 powerfull instruction- most single clock cycle execution

b. 32x8 general purpose Fully Static Operation.

c. Up to $16 \mathrm{MIPS}$ Throughput at $16 \mathrm{MHz}$.

d. On-chip 2-cycle Multiplier

2. Nonvolatile Program dan data Memories

a. 8K Bytes of In Syustem Self Programmable Flash.

b. B. Optional Boot Code Section with Independent Lock Bits.

c. 512 Bytes EPROM.

d. 512 Bytes Internal SRAM.

e. Programming lock for software security.

3. Peripheral Features

a. 2 bit timer / counter with separate prescaler and compare mode.

b. One 16 bits timer / counter with separate prescaler and compare mode.

c. Real Time Counter with Separate Oscillator

d. Four PWM Channels

e. 8-channel, 10-bit ADC 
8 Single-ended Channels

7 Differential Channels in TQFP Package Only

2 Differential Channels with Programmable Gain at 1x, 10x, or 200x

f. Byte-oriented Two-wire Serial Interface

g. Programmable Serial USART

h. Master/Slave SPI Serial Interface

i. Programmable Watchdog Timer with Separate On-chip Oscillator

j. On-chip Analog Comparator

4. Special Microcontroller Features

a. Power-on Reset and Programmable Brown-out Detection

b. Internal Calibrated RC Oscillator

c. External and Internal Interrupt Sources

d. Six Sleep Modes: Idle, ADC Noise Reduction, Power-save, Powerdown, Standby and Extended Standby

5. 1/0 and Packages

a. 32 Programmable //O Lines

b. 40-pin PDIP, 44-lead TQFP, and 44-pad QFN/MLF

6. Operating Voltages

a. $2.7-5.5 \mathrm{~V}$ for ATmega16L

b. $4.5-5.5 \mathrm{~V}$ for ATmega16

6. Speed Grades

a. 0 - $8 \mathrm{MHz}$ for ATmega16L

b. 0 - $16 \mathrm{MHz}$ for ATmega16

7. Power Consumption @ $1 \mathrm{MHz}, 3 \mathrm{~V}$, and $25^{\circ} \mathrm{C}$ for ATmega16L

a. Active: $1.1 \mathrm{~mA}$

b. Idle Mode: $0.35 \mathrm{~mA}$

c. Power-down Mode: $<1$ ì

Konfigurasi pin pada IC ATmega 16 dapat dilihat dibawah ini. 


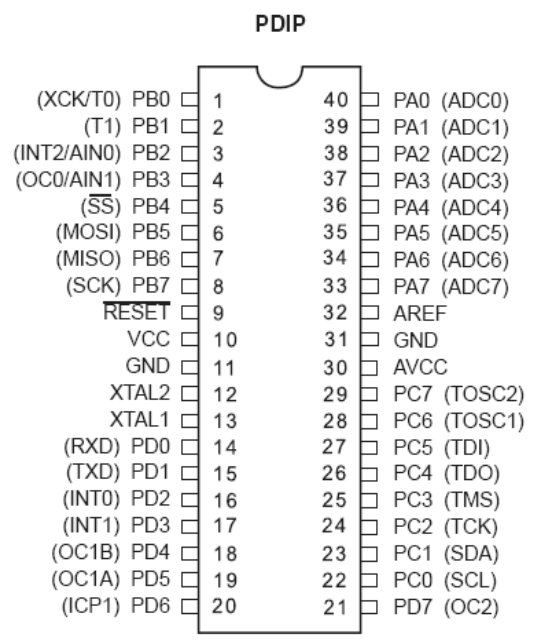

Gambar 1: konfigurasi pin-pin Atmega16

Deskripsi dari pin-pin ATmega16 adalah sebagai berikut :

1. VCC : Supply tegangan digital

2. GND : Ground

3. Port A : Port A sebagai input analog ke A/D konverter. Port A juga sebagai 8 bit bidirectional port I/O, jika A/D konverter tidak digunakan. Pin- pin port dapat menyediakan resistor resistor internal pull up. Ketika port A digunakan sebagai input dan pull eksternal yang rendah akan menjadi sumber arus jika resistor pull up diaktifkan. Pin - pin port A akan tri state ketika kondisi reset menjadi aktif sekalipun clock tidak aktif.

4. Port B juga sebagai 8 bit bi directional port I/O menyediakan resistor resistor internal pull up. Buffer output port B mempunyai karakteristik drive yan simetris dengan kemampuan kedua sink dan source yang tinggi. Sebagai input, port B yang mempunyai pull eksternal yang rendah akan menjadi sumber arus resistor pull up diaktifkan. Pin - pin port B akan tri state ketika kondisi reset menjadi aktif sekalipun clock tidak aktif.

5. Port C juga sebagai 8 bit bi directional port I/O menyediakan resistor resistor internal pull up. Buffer output port B mempunyai karakteristik drive yan simetris dengan kemampuan kedua sink dan source yang tinggi. Sebagai input, port B yang mempunyai pull eksternal yang rendah akan menjadi sumber arus resistor pull up diaktifkan. Pin - pin port $\mathrm{C}$ akan tri state ketika kondisi reset menjadi aktif sekalipun clock tidak aktif. 
7. RESET : Sebuah low level pulsa yang lebih lama daripada lebar pulsa minimum pada pin ini akan menghasilkan resest meskipun clock tidak berjalan.

8. XTAL1 : Input inverting penguat oscilator dan input internal clock operasi rangkaian .

9. XTAL2 : Output dari rangkaian inverting penguat oscilator.

10. AVCC : Pin supply tegangan untuk port A dan A/D konverter. Sebaiknya eksternalnaya dihubungkan ke VCC melalui low pass filter.

11. AREF : pin referensi analog untuk A/D konverter.

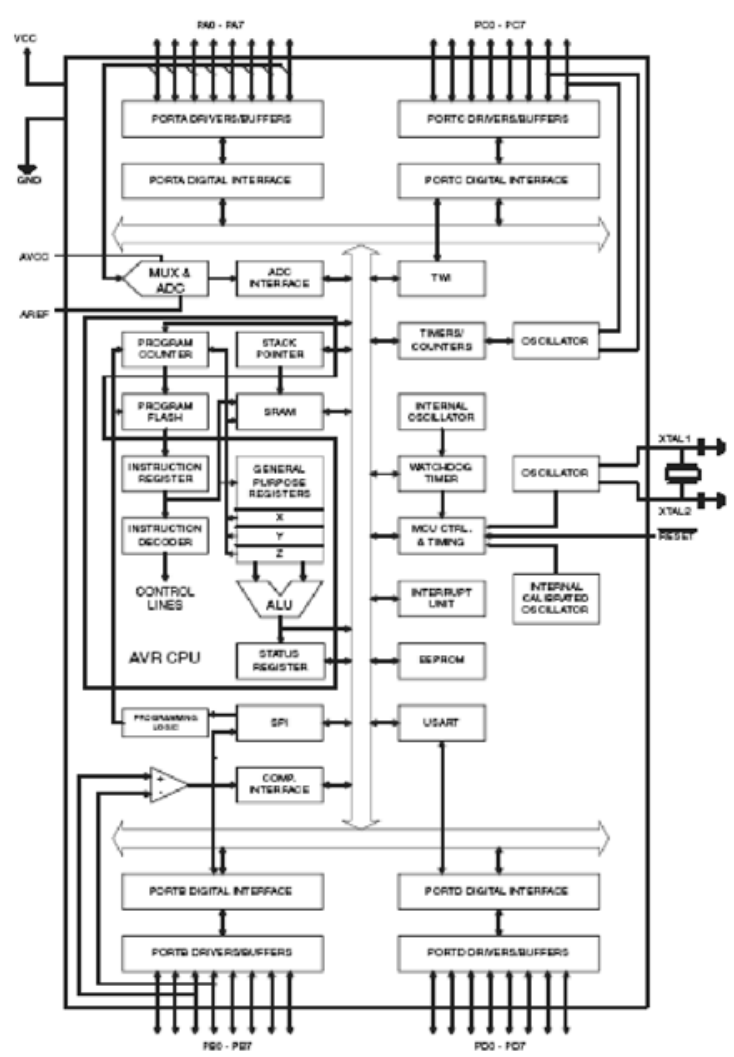

Gambar2 : Blok diagram Atmega16

\section{B. FlashMemory}

AVR menggunakan arsitektur hardvard ( dengan memori dan bus terpisah untuk program dan data ). ATmega16 memiliki 16K Byte flash memori dengan lebar 1 atau 32 bit. Kapasitas memori itu sendiri terbagi menjadi dua bagian yaitu 
bagian boot program dan aplikasi program. flash mempunyai kemampuan mencapai 10.000 writeand erase.

\section{Pin sebagai input / output digital}

ATmega16 mempunyai empat buah port yang bernama PortA,PortB, PortC, dan PortD.Keempat port tersebut merupakan jalur bi directional dengan pilihan interernal pull up. Tiap port mempunyai tiga buah register bit yaitu DDxn, PORTxn, dan PINxn. Huruf ' $x$ 'mewakili nomor bit . bit DDxn terdapat pada I/O address DDRx, bit PORTxn terdapat pada I/O address PORTX dan bit PINx terdapat Applisatuon Flaspåđd? I/O address PI Nx. Bila DDxn diset 1 maka Px berfungsi sebagai pin input. Bila PORTxn diset 1 pada saat pin terkonfigurasi sebagai pin input, maka resistor pullup akan diaktifkan.
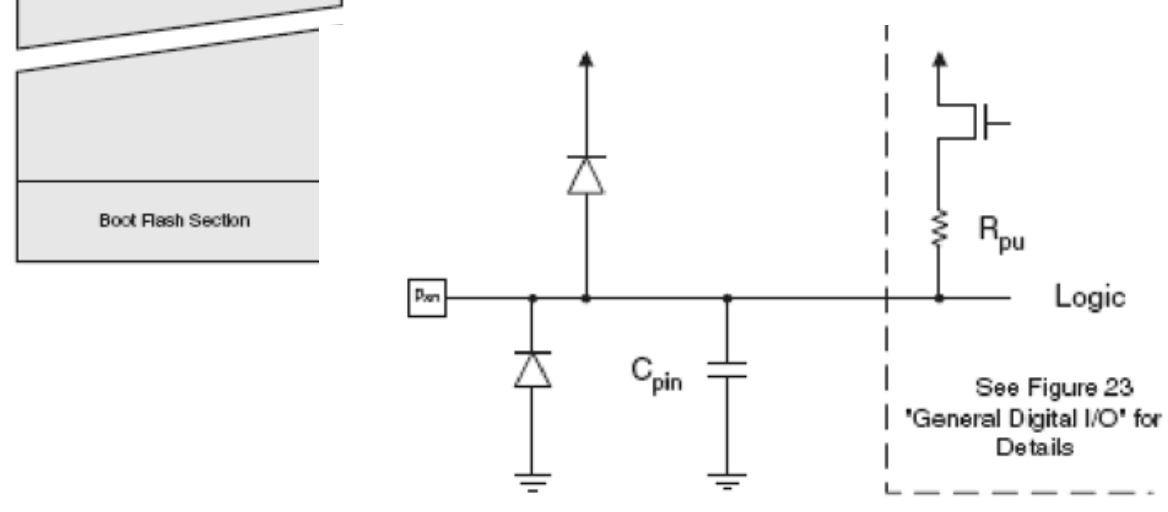

Gambar 4 : konfigurasi sebagai pin input dan resistor pull-up 


\section{Timer/ counter}

Timer/counter adalah tujuan umum single channel, module 8 bit timer/ counter. Beberapa fasilitas channel dari timer counter antara lain :
a. counter channel tunggal.
b. pengosongan data timer berdasarkan data pembanding
c. bebas glitch, tahap yang tepat pulse width modulator (PWM).
d. Pembangkit frekuensi
e. Even counter eksternal

Gambar 5: blok diagram 8 bit timer/counter

\section{Serial pada ATmega16}

Universal synchronous dan asynchronous pemancar dan penerima signal adalah suatu alat komunikasi serial yang sangat fleksibel. J enis yang utama adalah:

a. operasi full duplex (register penerima dan pengirim serial dapat berdiri sendiri)

b. Operasi synchronous dan asynchronous

c. Master atau slave mendapat clock dengan operasi synchronous

d. Pembangkit baud rate dengan resolusi tinggi

e. Dukung frames serial dengan 5, 6, 7, 8, atau 9 data bit dan 1 atau 2 stop bit.

f. Tahap odd and parity even 
g. Pendeteksian data overrun

h. Pendeteksian framming error

i. Pemfilteran gangguan (noise) meliputi pendeteksian bit false start dan pendeteksian low pass filter

j. Tiga interrupt terdiri dari TX complete, TX data register empty, dan RX complete.

k. Mode komunikasi multi processor

I. Mode komunikasi double speed asynchronous

USART harus diinisialisasi terlebih dahulu sebelum komunikasi manapun dapat berlangsung. Proses inisialisasi normalnya terdiri dari pengesetan baud rate, penyetingan frame format dan pengaktifan pengirim atau penerima tergantung pada pemakaian. Untuk interrupt menjalankan operasi USART, global intrrupt flag (penanda) sebaiknya dibersihkan ketika inisialisasi ulang dengan mengubah baud rate atau frame format, untuk meyakinkan bahwa tidak ada transmisi berkelanjutan sepanjang periode register yang diubah

\section{CodeVision AVR}

CodeVisionAVR merupakan software C-cross compiler, dimana program dapat ditulis menggunakan bahasa- $C$. Dengan menggunakan pemrograman bahasaC diharapkan waktu disain (deleloping time) akan menjadi lebih singkat. Setelah program dalam bahasa- $C$ ditulis dan dilakukan kompilasi tidak terdapat kesalahan (error) maka proses download dapat dilakukan. Mikrokontroler AVR mendukung sistem download secara ISP (In-System Programming).

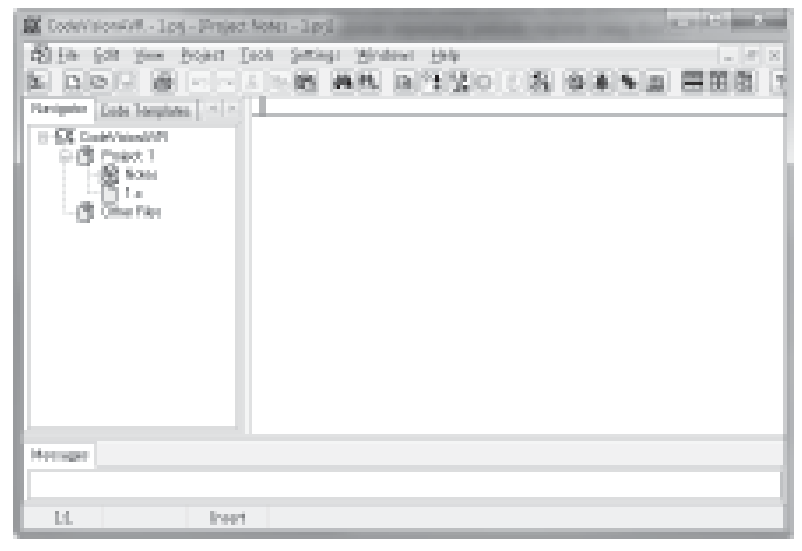

Gambar 6: Tampilan Codevision 
Untuk selanjutnya fasilitas-fasilitas lainnya dapat disetting sesuai kebutuhan dari pemrograman. Setelah selesai dengan CodeWizardAVR, selanjutnya pada menu File, pilih Generate, Save and Exit dan simpan pada direktori yang diinginkan.

\section{Design Power Supply dan Regulator}

Untuk Power Supply digunakan 2 buah baterai (aki kering), masing-masing memiliki nilai nominal $12 \mathrm{~V}$, sehingga total tegangan supply adalah 24 Volt. Nilai tegangan ini untuk men-supply motor DC yang digunakan. Sedangkan untuk rangkaian kontrolnya ditambah dengan rangkaian regulator supaya menghasilkan nilai tegangan +5 volt. Design rangkaian regulator diharapkan dapat memisahkan ground antara rangkaian driver motor dan rangkaian kontrolnya. Hal ini dimaksudkan supaya arus balik dari motor tidak mengganggu kinerja dari rangkaian kontrol, dimana arus balik ini dapat menyebabkan mikrokontroler menjadi "hang".

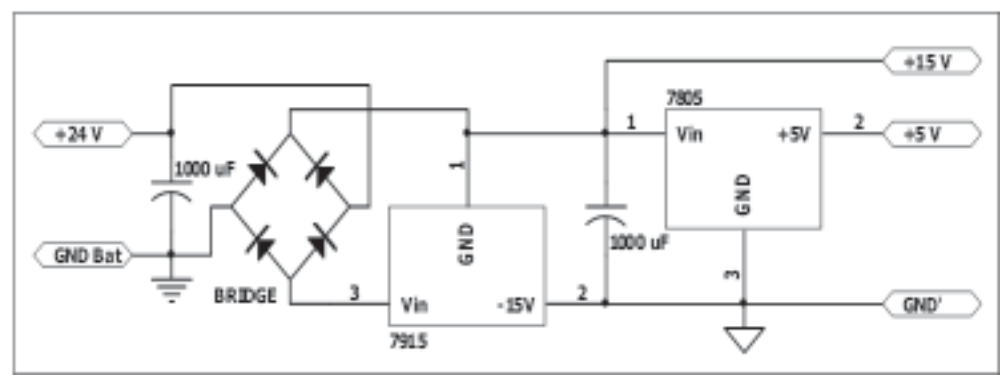

Gambar 7: Desain Power Supply dan Regulator

\section{Sensor Arus}

Sensor adalah komponen kritis dalam sistem kendali motor. Sensor digunakan untuk mendeteksi arus, posisi, kecepatan dan arah gerakan motor. Akhir-akhir ini kemajuan dalam teknologi memiliki perkembangan yang akurat dan reabilitas dari sensor, selain itu harganya lebih murah. Sekarang banyak sensor yang tersedia yang mampu menggabungkan rangkaian sensor dan sinyal, ke dalam satu IC. Pada kebanyakan sistem kendali motor, sensor digunakan untuk menyediakan informasi balik pada motor. Sensor ini digunakan dalam perulangan kontrol dan untuk memperbaiki reliabilitas dengan mendeteksi kesalahan kondisi yang dapat merusak motor. Sebagai contoh, gambar 3.1 menyediakan blok diagram pada sistem control motor DC untuk menunjukkan sensor balik yang ditujukan untuk kendali motor tertentu. Ada 3 sensor arus paling populer dalam aplikasi pengendalian motor adalah: 


\section{Resistor shunt \\ Sensor Hall Effect \\ arus trafo}

Resistor shunt adalah sensor arus yang popular karena sensor ini menyediakan keakuratan pengukuran pada nilai rendah. Sensor Hall Effect digunakan secara luas karena sensor ini menyediakan pengukuran yang tidak intrusive dan tersedia dalam sebuah paket IC kecil yang menggabungkan sirkuit sensor dan sinyal. Pengubah arus yang ditangkap juga merupakan teknologi sensor yang populer, khususnya dalam aplikasi arus atau pengamatan aliran arus AC.

\section{Optocoupler}

Optocoupler mempunyai sumber yaitu optical yang di copel sebagai receiver. Kedua sumber dan receiver ditutup dalam satu kemasan. Alat ini mempunyai dua atau lebih terminal input yang disambung untuk sumber dan dua atau lebih terminal output yang dihubungkan untuk output dari receiver. Meskipun coupling optical, rangkaian input dan outputnya terpisah dari rangkaian elektrik, 12 optocoupler mempunyai tahanan isolasi pada orde $10 \mathrm{ohm}$, kapasitansinya lebih kecil dari picofarad, dan kekutan tegangan isolasinya hanya beberapa kilovolt. Oleh karena itu, alat ini disebut optoisolator sebaai tujuan utamanya, disamping coupling optical, optocoupler memberikan isolasi elektrik yang bagus disamping rangkaian input dan output. Dengan optocoupler, kita bisa menyambungkan rangkaian yang sensitive dengan supply yang terpisah, memisahkan masalah efek dari arus ground dan digunakan pada rangkain digital yang sensitive untuk driver peralatan daya besar.sejak pertama kali muncul, optocoupler menjadi teknologi control yang umum digunakan untuk peralatan listrik dengan daya yang besar. Optocoupler mempunyai dua rangkaian yang terpisah. Rangkaian input terdiri dari sumber radiasi. Fluks dari sumber yang dikopel untuk detektor pada bagian rangkaian output,yang biasanya disebut sebagai receiver. Receiver mempunyai dua atau lebihterminal output. Disebutkan, fitur utama dari alat ini adalah sumber dan receiver dengan kopling optical.

\section{G. Konfigurasi Sistem}

Secara umum, sistem sensor pada Robot Otomatis terdiri dari dua bagian dasar, yaitu bagian perangkat keras (hardware) dan bagian perangkat lunak (software). Sistem sensor tersebut akan menyediakan data bagi sistem kontrol untuk mengatur jalannya robot. Sensor yang digunakan berupa sensor arus untuk mendeteksi adanya objek yang dipegang. Perangkat keras yang digunakan sebagai sistem pengendali disini adalah rangkaian mikrokontroler Atmega 16. Data masukan 


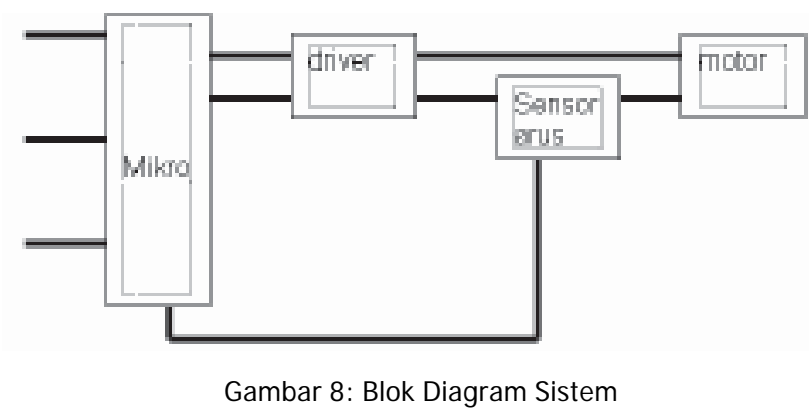

\section{Perancangan Dan Pembuatan Sensor Arus}

Sistem sensor yang digunakan adalah sensor arus. Rangkaian sensor terdiri dari 2 bagian, yaitu rangkaian sensor itu sendiri dan rangkaian driver motor. Rangkaian sensor terdiri dari resistor sebagai piranti yang mendeteksi kekuatan jepit memegang

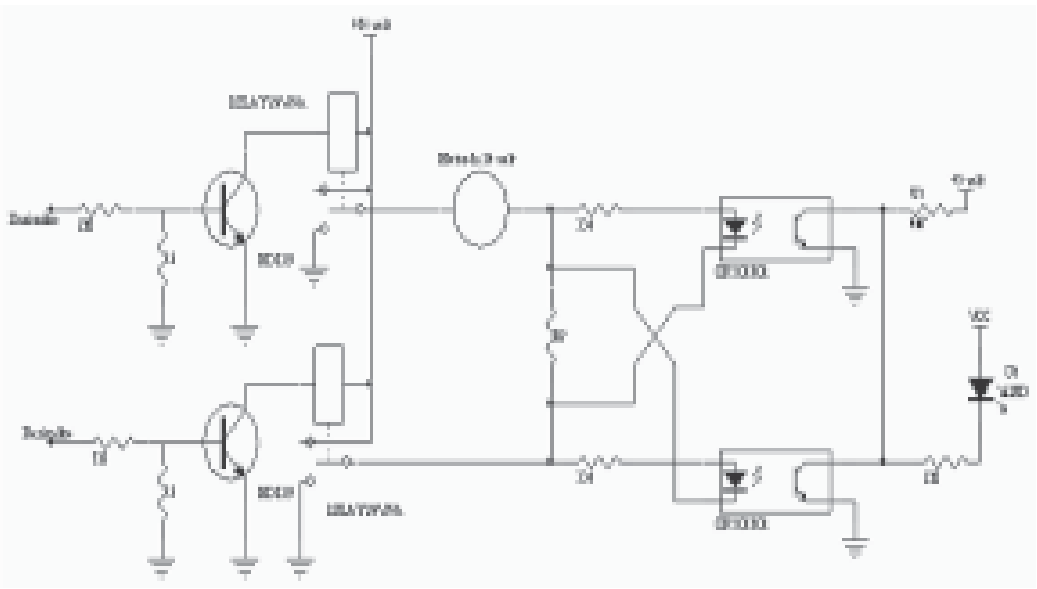

Gambar 9 : Rangkaian Sensor Arus

Pada rangkaian diatas menjelaskan bagian-bagian dari sensor arus. Ada beberapa bagian diantaranya, rangkaian driver motor yang menggunakan relay, dan rangkaian sensor arus itu sendiri. Driver motor berfungsi sebagai piranti yang bertugas untuk menjalankan motor baik mengatur arah putaran motor maupun kecepatan putar motor. Macam driver motor diantaranya adalah:

Driver Kontrol Tegangan

Dengan driver motor kontrol tegangan menggunakan level tegangan secara langsung untuk mengatur kecepatan dari putaran motor. 


\section{Driver PWM}

Dengan PWM kita dapat mengatur kecepatan motor dengan memberikan pulsa dengan frekwensi yang tetap ke motor, sedangkan yang digunakan untuk mengatur kecepatan adalah duty cycle dari pulsa yang diberikan.

Driver $\mathrm{H}$

Driver type $\mathrm{H}$ digunakan untuk mengontrol putaran motor yang dapat diatur arah putarannya CW (searah jarum jam) maupun CCW (berlawanan jarum jam). Driver ini pada dasarnya menggunakan 4 buah transistor untuk switching (saklar) dari putaran motor dan secara bergantian untuk membalik polaritas dari motor.

\section{Pengujian Dan Analisa}

Dalam hal ini akan dibahas tentang pengujian berdasarkan perencanaan dari sistem yang dibuat. Program pengujian disimulasikan di suatu sistem yang sesuai. Pengujian ini dilaksanakan untuk mengetahui kehandalan dari sistem dan untuk mengetahui apakah sudah sesuai dengan perencanaan atau belum. Pengujian pertama-tama dilakukan secara terpisah, dan kemudian ke dalam dilakukan ke dalam dilakukan ke dalam sistem yang telah terintegrasi. Pengujian yang dilakukan pada tahap ini antara lain pengujian sensor arus.

\section{Pengujian}

Untuk mengetahui nilai tegangan output pada VR dari sensor arus pada saat jepit memegang objek, seperti tampak pada gambar pengukuran tegangan pada motor penjepit. Untuk mengetahui nilai tegangan output optocoupler dari sensor arus pada saat jepit memegang objek, seperti tampak pada gambar pengukuran tegangan output pada optocoupler. Untuk mengetahui nilai arus yang dihasilkan oleh motor penjepit pada saat dalam kondisi memegang objek, seperti tampak pada gambar pengukuran arus pada motor penjepit.

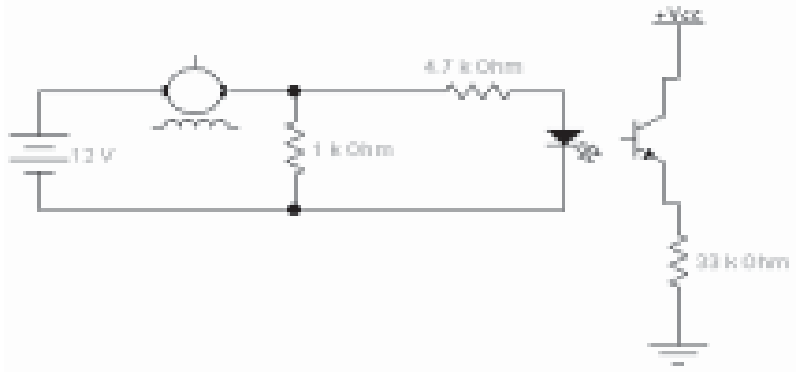

Gambar 10: Rangkaian pengujian sensor arus 


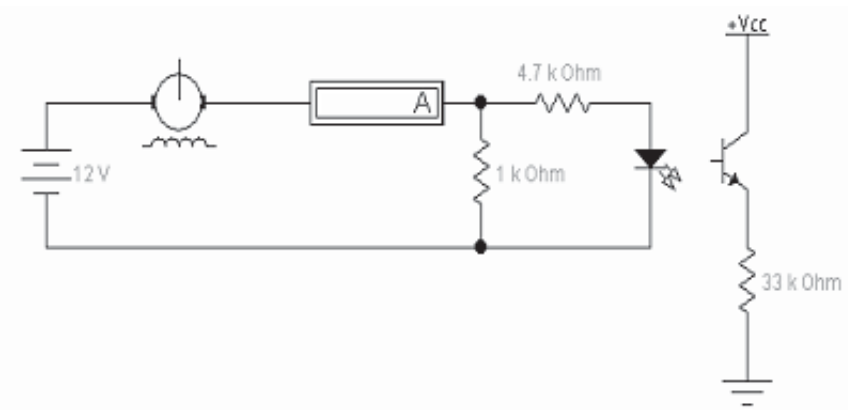

Gambar 11: pengukuran arus pada motor penjepit

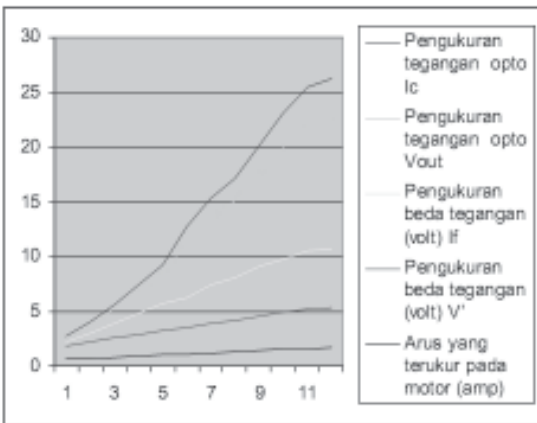

Gambar 12: pengukuran tegangan pada motor penjepit

\begin{tabular}{|c|c|c|c|c|}
\hline \multirow[t]{2}{*}{$\begin{array}{l}\text { Arus yang } \\
\text { terukur pada } \\
\text { motor (amp) }\end{array}$} & \multicolumn{2}{|c|}{$\begin{array}{l}\text { Penguknuran beda } \\
\text { tegangym } \\
\text { (volt) }\end{array}$} & \multicolumn{2}{|c|}{$\begin{array}{l}\text { Penguluman } \\
\text { tegrngan } \\
\text { opto }\end{array}$} \\
\hline & $V^{\prime}$ & If & Vout & Ic \\
\hline$\overline{1}$ & $\overline{1.2}$ & 0212 & 0.2 & 0.0606 \\
\hline 1.5 & 1.75 & 1382 & 1.8 & 0.545 \\
\hline 2 & 2.25 & 2.44 & 4.6 & 1.39 \\
\hline 2.5 & 2.3 & 3.61 & 7.8 & 2.36 \\
\hline 3 & 3.4 & 4.89 & 12 & 3.63 \\
\hline
\end{tabular}

Gambar 13: pengukuran tegangan output pada optocoupler 
2. Hasil Pengukuran

Tabel 1 : Pengujian Sensor Arus dengan Vr 2.2 ohm

\begin{tabular}{|c|c|c|c|c|}
\hline \multirow[t]{2}{*}{$\begin{array}{l}\text { Arus yang } \\
\text { terukur pada } \\
\text { motor (amp) }\end{array}$} & \multicolumn{2}{|c|}{$\begin{array}{l}\text { Pengukruran bedis } \\
\text { tegangan } \\
\text { (volly) }\end{array}$} & \multicolumn{2}{|c|}{$\begin{array}{l}\text { Pengulburnal } \\
\text { tegangan } \\
\text { opto }\end{array}$} \\
\hline & $V^{\prime}$ & If & Vout & Ic \\
\hline 1 & 1.2 & 0.212 & 0.2 & 0.0606 \\
\hline 1.5 & 1.75 & 1382 & 1.8 & 0.545 \\
\hline 2 & 2.25 & 2.44 & 4.6 & 1.39 \\
\hline 2.5 & 2.3 & 3.61 & 7.8 & 2.36 \\
\hline 3 & 3.4 & 4.89 & 12 & 3.63 \\
\hline
\end{tabular}

Pada pengukuran tabel diatas optocoupler digunakan untuk menghasilkan nilai logika " 0 " dan " 1 " sebagai input kontroler. Pengujian dilakukan dengan cara mengukur nilai tegangan output sensor saat penjepit memegang objek. Komponen yang kita gunakan:

$$
\begin{aligned}
& \mathrm{VR}=2,2 \mathrm{Ohm} \\
& \mathrm{Rbeban}=33 \mathrm{k} \mathrm{Ohm} \\
& \mathrm{Rp}=4 \mathrm{k} 7 \mathrm{Ohm}
\end{aligned}
$$

\begin{tabular}{|c|c|c|c|c|}
\hline \multirow{2}{*}{$\begin{array}{c}\text { Arus yang } \\
\text { terukus pada } \\
\text { motor (amp) }\end{array}$} & \multicolumn{2}{|c|}{$\begin{array}{c}\text { Pengukruran bedn } \\
\text { tegangan } \\
\text { (volt) }\end{array}$} & \multicolumn{2}{c|}{$\begin{array}{c}\text { Peaguhuran } \\
\text { tegangan } \\
\text { opto }\end{array}$} \\
\cline { 2 - 5 } & $\mathrm{V}^{3}$ & If & Vout & Ic \\
\hline 1 & 1.2 & 0.212 & 0.2 & 0.0606 \\
\hline 1.5 & 1.75 & 1.382 & 1.8 & 0.545 \\
\hline 2 & 2.25 & 2.44 & 4.6 & 1.39 \\
\hline 2.5 & 2.3 & 3.61 & 7.8 & 2.36 \\
\hline 3 & 3.4 & 4.89 & 12 & 3.63 \\
\hline
\end{tabular}

Gambar 14 : Grafik Pengujian Sensor Arus dengan Vr 2.2 ohm

Tabel 2 : Pengujian Sensor Arus Motor Besar dengan Vr 1.2 ohm

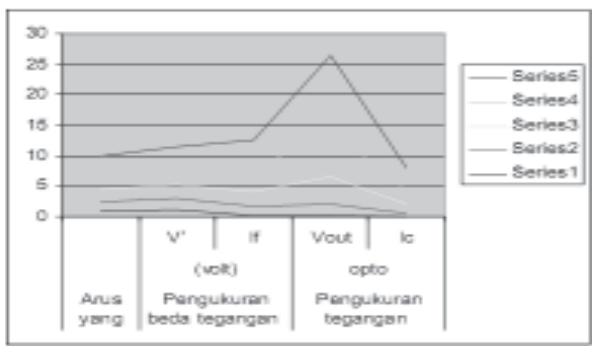




\begin{tabular}{|c|c|c|c|c|}
\hline \multirow[t]{2}{*}{$\begin{array}{l}\text { Ares yang } \\
\text { terikur pada } \\
\text { wetce (anep) }\end{array}$} & \multicolumn{2}{|c|}{$\begin{array}{c}\text { Peguluras beda } \\
\text { tegangen } \\
\text { (toil) }\end{array}$} & \multicolumn{2}{|c|}{$\begin{array}{c}\text { Peapluas } \\
\text { epragex } \\
\text { opto }\end{array}$} \\
\hline & $\mathrm{V}^{+}$ & If & Vout & Ic \\
\hline 0.15 & 1 & & 0.1 & \\
\hline 02 & 1.6 & 0.0105 & 1 & 0.00301 \\
\hline 025 & 8 & 1.19148 & 2 & 0606 \\
\hline 0.3 & 2.4 & 2.765 & 4 & 1.212 \\
\hline 0.35 & 2.6 & 3.1914 & 6 & 1.813 \\
\hline 0.4 & 3 & 400425 & $\mathrm{E}$ & 2424 \\
\hline 0.45 & 32 & 4.468 & 105 & 3.18 \\
\hline 6.5 & 3.6 & 5316 & 12 & 3696 \\
\hline
\end{tabular}

Gambar 15 :Grafik Pengujian Sensor Arus dengan Vr 1.2 ohm

Tabel 3: Pengujian Sensor Arus dengan Vr 6.6 Ohm
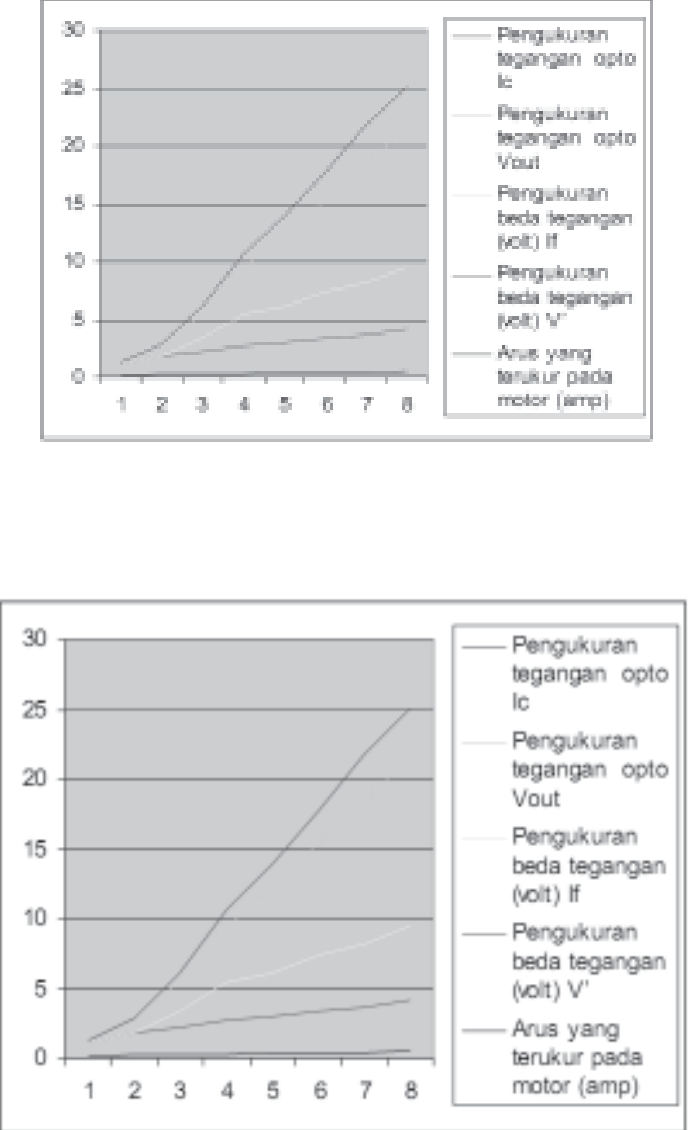

Gambar 16 grafik: Pengujian Sensor Arus dengan Vr 6.6 ohm 
Tabel 4: Pengujian Sensor Arus dengan Vr 6 ohm

\begin{tabular}{|c|c|c|c|c|}
\hline \multirow[t]{2}{*}{$\begin{array}{l}\text { Asus yang } \\
\text { terukur padz } \\
\text { moter (amp) }\end{array}$} & \multicolumn{2}{|c|}{$\begin{array}{c}\text { Peogukuram beda } \\
\text { tegrangran } \\
\text { (voli) }\end{array}$} & \multicolumn{2}{|c|}{$\begin{array}{c}\text { Penquikuran } \\
\text { tegingan } \\
\text { opto }\end{array}$} \\
\hline & $V^{\prime}$ & If & Vout & Ic \\
\hline 02 & 1.4 & 0.638 & 0.4 & 0.1212 \\
\hline 0.25 & 1.6 & 1.0638 & 1.15 & 0.348 \\
\hline 03 & 2 & 1.91 & 3 & 0.900 \\
\hline 035 & 22 & 2.34 & 4.8 & 1.45 \\
\hline 0.4 & 2.6 & 3.19 & 6.4 & 1939 \\
\hline 0.45 & 2.8 & 3.61 & 8 & 2.42 \\
\hline 0.5 & 3.4 & 4.89 & 11.2 & 339 \\
\hline 655 & 3.6 & 5.319 & 12 & 3.63 \\
\hline
\end{tabular}

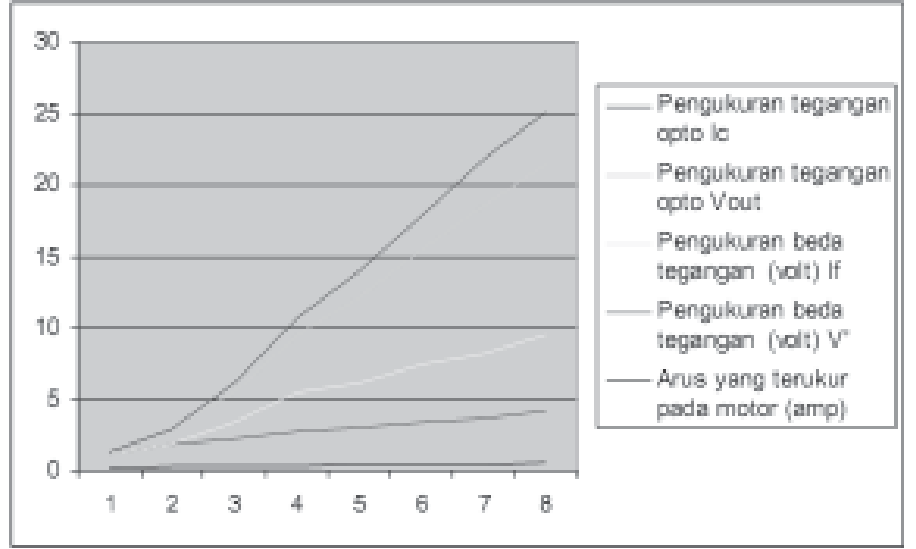

Gambar 17 :Grafik Pengujian Sensor Arus dengan Vr 6 ohm

\section{Analisa}

Setelah melakukan perencanaan dan pembuatan sistem kemudian dilakukan pengujian, maka dapat diambil beberapa analisa tentang sistem kerja dari rangkaian sensor arus dan mikrokontroler ATmega16, sebagai berikut :

1. Dalam pembuatan hardware, pengkabelan dari rangkaian dan tata letak komponen yang disusun seefisien mungkin sehingga tidak menyita banyak 
tempat, sedangkan software untuk kontrol dari sensor algoritmanya dibuat seefisien mungkin supaya aksesnya bisa cepat dan tidak terlalu membebani proses kontrol dari robot secara keseluruhan.

2. Desain mekanik juga perlu diperhatikan dalam mengatur kecepatan dari robot. Semakin rendah desain mekaniknya, maka kecepatan juga akan semakin optimal.

3. memerlukan delay sebentar saat kondisi dari motor diam ke bergerak karena pada saat itu $\mathrm{Rm}<<$ sama seperti kondisi overload

Nilai tegangan output dari sensor saat memegang objek tidak sama Resistor shunt dihubungkan secara serial dengan motor, sedangkan input dari opto-coupler dihubungkan parallel dengan resistor shunt. Ketika arus pada rangkaian meningkat, tegangan pada resistor shunt juga akan naik. Pada tegangan tertentu optocoupler akan aktif sehingga dari opto tersebut akan memberi kan logika 0 yang akan diolah oleh mikrokontroller. Dari data yang kita peroleh kita dapat menghitung transfer ratio optocoupler dan dapat ditarik kesimpulan apabila motor ditahan otomatis beban dari motor besar sehingga menimbulkan beda tegangan yang akan mengatifkan optocoupler .

Dengan mendeteksi perbedaan level tegangan output dari sensor tersebut, sensor arus dapat digunakan untuk mendeteksi apakah robot otomatis sudah benarbenar memegang objek

\section{KESIMPULAN}

Setelah melakukan perencanaan dan pembuatan sistem kemudian dilakukan pengujian dan analisanya, maka dapat diambil beberapa kesimpulan tentang sistem kerja dari rangkaian sensor arus dan mikrokontroler ATmega16, sebagai berikut :

Kelemahan dari sistem yang dibuat antara lain :

a. Penentuan nilai kekuatan jepit juga bergantung pada nilai resistor variabel yang dipasang, Rbeban, serta Rp.

b. Pengesetan sensor dilakukan secara manual, dilakukan dengan cara penjepit dalam kondisi memegang objek dan diberi beban. Jika objek tidak jatuh kekutan penjepit dari robot otomatis sesuai yang dihrapkan.

Kelebihan dari sistem yang dibuat antara lain :

a. Data kecepatan yang diambil sudah ada dalam memori dan langsung diambil sesuai scanning sensor, sehingga proses berlangsung lebih cepat

b. Rangkaian yang digunakan sangat simpel dapat hanya dengan menggunakan 
c. beda tegangan vr dan optocoupler yang difungsikan sebagai inputan ke mikrokontroller.

d. Memerlukan delay sebentar saat kondisi dari motor diam ke bergerak karena pada saat itu $\mathrm{Rm}<<$ sama seperti kondisi overload

e. Optocoupler akan bekerja normal pada saat nilai transfer ratio mendekati nilai 50\%-100\%. Apabila keadan tersebut terpenuhi otomatis alat akan bekerja sesuai dengan yang diharapkan.

\section{SARAN}

Untuk mendapatkan performa yang lebih baik dari sistem robot ini, dapat digunakan kontroler yang lebih baik dan cepat untuk mengolah data secara lebih real time. Output sensor juga dapat diambil tegangan analognya dan diubah oleh optocoupler menjadi besaran biner yang kemudian diproses pada kontroler, sehingga tidak lagi memerlukan komparator dan pengesetan secara manual pada tegangan referensinya. Penentuan kekuatan motor penjepit dapat dirumuskan secara lebih spesifik, sehingga tidak perlu melakukan percobaan berulang kali.. Selain itu dalam pembuatan robot line tracer, perlu diperhatikan desain mekanik dan peletakkan sensor sesuai kondisi lapangan. Semoga apa yang telah disampaikan disini dapat berguna untuk para pembaca sekalian, terutama dalam pembuatan robot untuk kontes robot yang selalu diadakan setiap tahun. Segala saran, kritik dan masukan yang bersifat membangun sangat diharapkan untuk kesempurnaan penelitian ini nantinya.

\section{DAFTAR PUSTAKA}

1. Moh Ibnu Malik, Anistardi (1996), "Bereksperimen dengan Mikrokontroller Atmega16", PT Elex Media Komputindo, J akarta.

2. Kao, C.K (1982). Optical Fiber Systems. New York: McGraw-Hill Publishing Co.

3. Palais, J.C. (1992). Fiber Optic Comunication. Englewood Cliffs, NJ : Prentice-Hall.

4. "current sensor Characteristics", www. microchip.com 